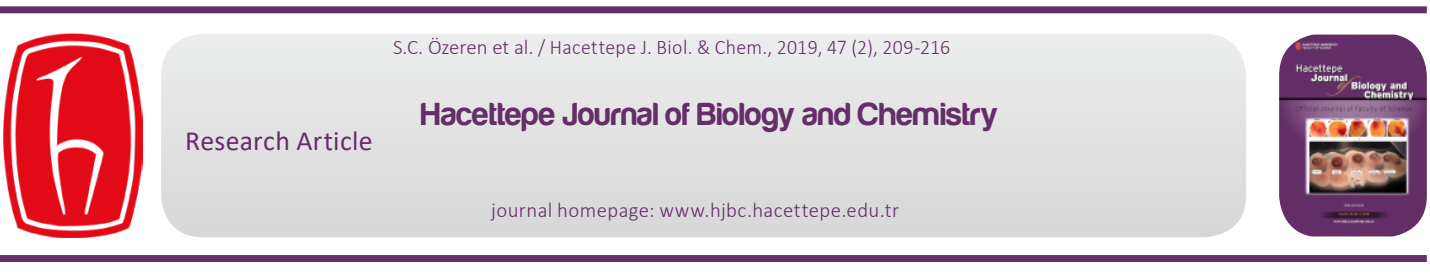

\title{
New Record and Comparison of Some Morphometric Characters of an Endemic Species Capoeta pestai (Pietschmann, 1933) (Pisces: Cyprinidae) Populations in Central Anatolia
}

\section{Endemik Bir Tür Olan Capoeta pestai (Pietschmann, 1933) (Pisces: Cyprinidae)'nin, Orta Anadolu'daki Popülasyonlarının Bazı Morfometrik Özelliklerinin Karşılaştırması ve Yeni Kaydı}

\author{
Saniye Cevher Özeren ${ }^{1 \oplus}$, Filiz Özdemir ${ }^{2}$, Füsun Erkakan ${ }^{2 \odot}$ \\ ${ }^{1}$ Department of Biology, Faculty of Science, Ankara University, Ankara, Turkey. \\ ${ }^{2}$ Department of Biology, Faculty of Science, Hacettepe University, Ankara, Turkey.
}

\section{A BSTRACT}

\begin{abstract}
- ndemic species, Capoeta pestai (Pietschmann, 1933) is newly recorded from the ibrala Stream, Yeşildere location, in - endorheic basin of the Central Anatolia. The known distribution of this species in Anatolia previously limited to the Lake Beyşehir and Eğirdir Basin systems and the river Melendiz in this area. The taxonomic characters of $C$. pestai population in the ibrala Stream was discussed with its other populations living in this endorheic basin. One-way analysis of variance (ANOVA) was applied to identify whether there were any statistically significant differences among the populations. Based on our results, there is a wide variation among the populations in terms of the number of scales on the line lateral, the number of 1st gill raker and some measurement taxonomic characters. In evaluating these findings, $C$. mauricii which described as a new species from Lake Beyşehir is the synonym to $C$. pestai.
\end{abstract}

Key Words

Capoeta pestai, new record, ibrala Stream, endorheic basin.

\section{öz}

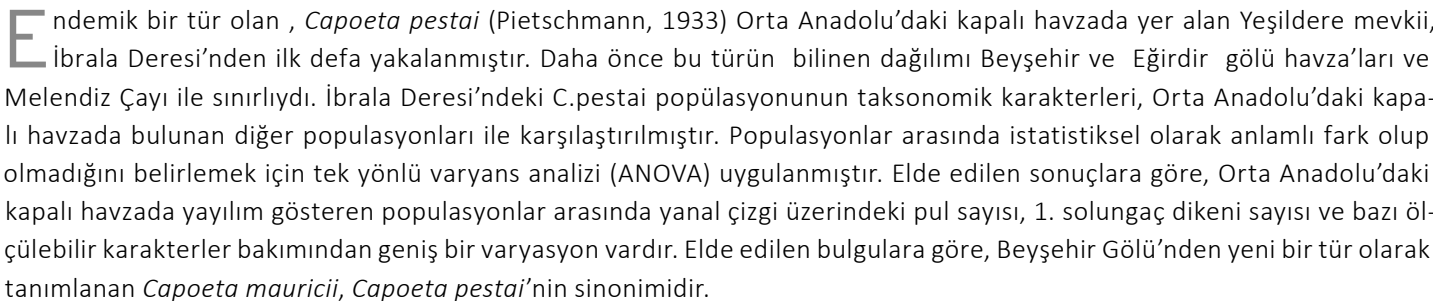

Anahtar Kelimeler

Capoeta pestai, yeni kayıt, ibrala Deresi, kapalı havza.

Article History: Received: Oct 23, 2018; Revised: Feb 15, 2019; Accepted: Apr 24, 2019; Available Online: Sep 15, 2019. DOI: $10.15671 /$ hjbc.623798

Correspondence to: F. Özdemir, Department of Biology, Faculty of Science, Hacettepe University, Ankara, Turkey.

E-Mail: dorafiliz@gmail.com 


\section{INTRODUCTION}

The genus Capoeta is a wide distribution from southern Chinese to Afghanistan, Aral Lake basin, Türkmenistan, and Anatolia. According to the Capoeta revision by Karaman[1], seven species (C.barroisi, C. buhsei, C. capoeta, C. fusca, C. pestai, C. tinca and C. trutta) of this genus and eleven subspecies of Capoeta capoeta distributed in Turkey and the Near East. Among these species, it was found that C. fusca and C. buhsei were not living in Anatolia. Banarescu [2] mentioned that the members of Capoeta range from Northwestern Anatolia and Transcaucasia to the Jordan River basin and eastern Iran. Afterwards, nine new species namely C. ekmekciae [3] C. baliki [4], C. banarescui [4], C. turani [5], C. erhani [6], C. caelestis [7], C. mauricii [8], C.oguzeli [9] and C. aydinensis [10] have been described from Çoruh River, Southwestern Blacksea, Çoruh River, Seyhan River, Ceyhan River, Göksu River, Beyşehir Lake, Yeşilırmak and Büyük Menderes River respectively. However, recent finding showed that $C$. turani and $C$. erhani are the synonyms to C. barroisi according to Erkakan and Özdemir [11], and C. banarescui and C.baliki are the synonyms to Capoeta tinca according to Özdemir [12].

An endemic species, C. pestai which was described firstly by Pietschmann [13], from the Lake Eğirdir. In the report of the World Conservation Union (IUCN) [14], the distribution of C.pestai is restricted to just one stream (Caykoy Creek; $10 \mathrm{~km}$ in length) and in southern Lake Egirdir in Central Anatolia, Turkey and evaluated as critically endangered species (CR). The taxonomic characters and distribution of this species was investigated by several researchers [1,15-17], and according to their results, the distribution of the species is extended from the Lake Eğirdir to the Lake Beyşehir and the river Melendiz in Central Anatolia.

Küçük et al. [17], examined the vertebrae counts and some skull bones such as jaw, operculum and circumorbital, and they mentioned that neither the differences between the Lake Eğirdir and Beyşehir populations were significantly important nor this differentiation was not significant at the species or subspecies level. Then Beyşehir Lake population was described as C. ma uricii by Küçük et al. [8].

The aim of this study was to establish the present geographic distribution of $C$. pestai in Turkey and to show the wide taxonomic variations among the populations inhabit in the endorheic basin of Central Anatolia and to determine whether the newly identified C. mauricii differs from C. pestai. Although this species is an endemic and critically endangered species (CR) according to the IUCN Red [14], the studies concerning to the morphometric characters and geographic distribution have been needed to aid in its protection.

\section{MATERIALS and METHODS}

Fish samples were taken during 1998, 2006 and 2011 with electro-fishing equipment from the Ibrala Stream $\left(37^{\circ} 08^{\prime} .32 .55^{\prime \prime} \mathrm{N}\right.$; $\left.33^{\circ} 36^{\prime} 48.18^{\prime \prime} \mathrm{E}\right)$, the Melendiz River


(Beyşehir Lake Basin: 3747'22.70”N; 3145'55.72"E), (Figure 1) and preserved both in \% 4 formaldehyde and \%95-96 ethyl alcohol and transported to the Ichthyology Museum in the Hacettepe University. 24 metric characters measurements were obtained with millimetric ruler and $0.05 \mathrm{~mm}$ sensitive calipers. The lateral line scale counts include the scales on the base of the caudal fin. The last 2 branched dorsal and anal fins are counted s 1 1 1/2 [18], ANOVA (analysis of varience) and CDFA (canonical discriminant function analyses) were applied to 43 variables to show the significant among the populations.

\section{RESULTS}

Capoeta pestai populations distributed in the endorheic basin of Central Anatolia were examined and compared with the previous study [17], for showing the wide taxonomic variations among the populations. Some morphometric and meristic data of examined samples and comparative materials are given in Table 1 and Table 2.

Ibrala Stream Population: HUIC: KKK-2; 10 specimens:

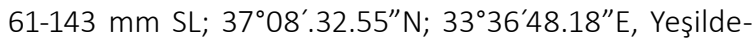
re-Taşkale, Karaman, Turkey, 18.07.2006-24.04.2007, Erk'akan coll.

Description: See Figure 2 for general appearance. Body is relatively high and laterally compressed. Maximum body depth is about 4 times in the standard length. Head relatively elongate and its length 26.2-32.3\% SL. Snout moderately pointed, its width and depth 26.4$31.3 \%$ and $26.5-30.9 \%$ in $\mathrm{HL}$ respectively. Mouth ventral and moderately arched and head length is mean 4.4 times longer than width of the mouth. The lower lip is well-developed. Barbel length is shorter than eye diameter and reaches the beginning of the eye. Last simple dorsal ray moderately ossified with 14-24 serrae on 
posterior margin, and its length is 0.6-0.8 times in its depth. Predorsal distance is about 1.6 times in the postdorsal distance. Anal fin is longer in females than males. Caudal fin forked. Caudal peduncle relatively stout and height of caudal peduncle is about 1.2 times in its length. Sexual dimorphism is present.

Kocasu Stream Population: HUIC: KKB-2; 13 specimens: 54-207 mm SL; 3747'22.70”N; 3145'55.72”E, Beyşehir, 22.08.1998-12.06.2007, Erk'akan collec.

Description: Body is relatively and laterally compressed. Maximum body depth is about 4 times in the standard length. Dorsal head profile convex. Mouth wide and arched. Lower lip well developed. Snout pointed. Length of the barbel is shorter than eye diameter and reaches to the beginning of the eye. Snout length is shorter than postorbital distance and snout length 33.3-39.5\% HL. Eye is relatively big and 2.9-3.8 times in head length. The outer margin of the dorsal ray is concave and last simple dorsal ray ossified with 12-26 serrae on posterior margin with well developed. The length of predorsal is 1.4-2.0 times longer than the length of postdorsal. Pectoral fins shorter than head length, its length 1.31.9 times in head length. Ventral fin is small and predorsal distance is almost equal preventral length (0.9). Caudal fin long and deeply forked. Height of the caudal peduncle is about 1.2 times in its length. Anal fin is longer in females than males. Preanal length is 1.2-1.4 times longer than predorsal length. Sexual dimorphism is present, males have tubercules on the head in the reproduction period.

Melendiz River Population: HUIC: KKK-3; KKK-3a: 9 spe-

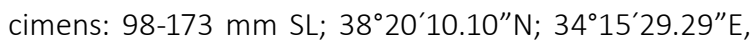
Aksaray, 31.07.2005-24.05.2006, Erk'akan collec.

Description: Body is relatively rounded and laterally compressed. Maximum body depth is about 4.2 times in the standard length. Head moderately pointed and convex in lateral view. Head length is about 2.3 times in its depth. Mouth is large and moderately arched. Lower lip is well-developed. Barbel length is shorter than eye diameter and reaches the beginning of the eye. Postorbital length is 1.5 times longer than snout length. The outer edge of the dorsal fin is convex and the last unbranched dorsal fin ray is strong with 15-24 serrae. Predorsal length is 1.5-1.9 times longer postdorsal length. Predorsal distance is equal preventral distance. Caudal fin is deeply forked. Length of the caudal peduncle is
0.8-1.3 times in its depth. Sexual dimorphism is present and anal fin is longer in female than in male. There are unclear small dusky spots on the body.

Sarıöz Stream Population: : SCFK-SDU/261, 12 specimens: 84,4-257mm SL; Sarıöz Stream, Beyşehir 11.11.2006

Description: Body is relatively rounded and fusiform. Maximum body depth is about 3,7 times in the standard length. Head moderately pointed and convex in lateral view. Mouth is large and moderately arched. Lower lip with developed lateral lobes. Barbel length is shorter than eye diameter and reaches the beginning of the eye. Dorsal fin with 3-4 simple and 71/2-81/2 branched rays, and the outer margin is convex. Anal fin with 3 simple and $51 \frac{1}{2}-6 \frac{1}{2}$ branched rays. Lateral line with $80-87$ scales; $18-22$ scales rows between lateral line and dorsal fin origin, 11-14 scales rows between lateral line and pelvic fin origin. Gill rakers are 16-18 on the outer side of the first gill arch [8].

\section{DISCUSSION}

The geographic distribution of Capoeta members, which is an Asia-origin, in Turkey, is substantiated by the connection of Anatolian inland lake with West Asia freshwater and numerous endemic species belong to Cyprinidae became diversified because of cutting this connection [2].

Some meristic and metric characteristics of $C$. pestai population inhabited in the Ibrala Stream was compared with other population found in Turkey [17], and these results were given in Table 1 and 2 .

When we compared some meristic characters of $C$. pestai populations in the Central Anatolia, the lowest lateral line scale number was found 77 in the Bakaran Stream flowing into Beyşehir Lake [17], whereas, it was maximum 99 in the Ibrala Stream. Moreover, the highest gill raker number was recorded 25 in the Çayköy Stream [17]. Watanabe [19], reported that in freshwater fishes, meristic characters such as fin ray counts, lateral line numbers, and gill rakers, often show some geographic or inter-population variations because of the reduction of isolation of populations. Additionally, experimental evidence showed that meristic characters (e.g. gill rakers, barbel lenght) are often subject to early phenotypic modification by environmental variations such as temperature, salinity, food [20-22]. 
According to the ANOVA and canonical discriminant function analyses, we determined that there are some differences in terms of the depth of body and height of anal fin in the standard length, postorbital length and mouth width in the head length among three populations, so population of $C$. pestai from the ibrala Stream showed low variability in morphological characters when compared to populations from others.

According to Küçük et al. [17], meristic characters of $C$. pestai populations in the lake Beyşehir and Eğirdir were similar, but they mentioned that the predorsal distance, depth of caudal peduncle and body were lower, but anal fin length is higher in the Eğirdir Lake Basin than Beyşehir Lake Basin. Moreover, they determined that although population of $C$. pestai from the Bakaran Stream flowing into Beyşehir Lake showed variability in terms of colour pattern and some morphological characters when compared to populations from the lake Beyşehir and Eğirdir, these differences were not important at a level of species or subspecies. In this study, we also observed that there were differences in terms of colour pattern in populations, caught from Melendiz River. It can be sure that there should be some differences among the population inhabited in different water bodies due to the physical and chemical properties of the lentic and lotic habitats.

The samples examined from the Kocasu Stream in the Beyşehir Lake Basin, the proportion of the standard length in the head length, body depth, dorsal fin height and the length of dorsal, ventral and pectoral fins length, and the proportion of eye diameter to the head length were found higher than the samples examined from the same basin by Küçük et al. [17]. In addition, we examined the same differences between the population in the Çayköy Stream and the Lake Eğirdir [17] and the population in the Ibrala Stream (Table 2).

Capoeta mauricii n. sp. is described from the Beyşehir Lake drainage, in Central Anatolia, Turkey[8]. It is distinguished from other Anatolian Capoeta by having the lips somewhat fleshy and lower lip with developed lateral lobes; a few irregular small black spots on the dorsal and lateral body, dorsal and caudal fins in individuals approximately smaller than $170 \mathrm{~mm} \mathrm{SL}$, and body, head and fins plain and without black spots in larger individuals (SL>200 mm); 80-87 total lateral line scales, 18-22 scales between dorsal fin origin and lateral line, 11-14 scales between the anal-fin origin and the lateral line, 16-18 gill rakers on outer side of first gill arch, and small black spots on head, body, and fins.

According to our result, metric and meristic characters show a wide variation within the Beyşehir population and at the same time, there is an overlap between populations. In addition, there are individuals larger than $200 \mathrm{~mm}$. with black spot on head and body(Figure 3). Vasil'eva [23], assumed that the principal factors of the modifications intrapopulation and inter-population variation of a character may have resulted from the age allometry and sexual dimorphism.

Table 1. Some Meristic Characters of Capoeta pestai populations.

\begin{tabular}{|c|c|c|c|c|c|c|c|}
\hline $\begin{array}{c}\text { Water } \\
\text { System } \\
\text { /Characters }\end{array}$ & $\begin{array}{l}\text { Ibrala } \\
\text { Stream } \\
\text { (Yeşildere- } \\
\text { Karaman) }\end{array}$ & $\begin{array}{l}\text { Melendiz } \\
\text { River } \\
\text { (Aksaray) }\end{array}$ & $\begin{array}{l}\text { Kocasu } \\
\text { Stream } \\
\text { (Sarıköy- } \\
\text { Beyşehir) }\end{array}$ & $\begin{array}{c}\text { Sarıöz } \\
\text { Stream } \\
\text { (Beyşehir) } \\
\text { [17] }\end{array}$ & $\begin{array}{c}\text { Bakaran } \\
\text { Stream } \\
\text { (Derebucak- } \\
\text { Konya) } \\
\text { [17] }\end{array}$ & $\begin{array}{c}\text { Çayköy } \\
\text { Stream } \\
\text { (Eğirdir) } \\
\text { [17] }\end{array}$ & $\begin{array}{l}\text { Lake Eğirdir } \\
\text { [17] }\end{array}$ \\
\hline & $n=10$ & $n=9$ & $n=13$ & $n=12$ & $n=15$ & $n=9$ & $n=5$ \\
\hline Dorsal fin ray & IV-8 1/2 & IV-7 1/2-8 1/2 & IV-8 1/2 & IV-8 1/2 & IV-8 1/2 & IV-8 1/2 & IV-8 1/2 \\
\hline Anal fin ray & III-5 1/2 & III-5 1/2-6 1/2 & III-5 $1 / 2$ & III-5 $1 / 2$ & III-5 1/2 & III-5 1/2 & 1||$-51 / 2$ \\
\hline Gill rakers & $12-15$ & $12-14$ & $14-17$ & $15-19$ & $11-13$ & $12-25$ & $16-17$ \\
\hline $\begin{array}{l}\text { Phrangeal } \\
\text { teeth }\end{array}$ & $2.3 .5-5.3 .2$ & $2.3 .5-5.3 .2$ & $2.3 .5-5.3 .2$ & $2.3 .5-5.3 .2$ & $2.3 .5-5.3 .2$ & $2.3 .5-5.3 .2$ & $2.3 .5-5.3 .2$ \\
\hline $\begin{array}{l}\text { Lateral line } \\
\text { scales }\end{array}$ & $85-99$ & $80-91$ & $81-91$ & $82-85$ & $77-83$ & $85-89$ & $82-88$ \\
\hline $\begin{array}{l}\text { Transverse } \\
\text { line scales }\end{array}$ & $16-19 / 10-13$ & $14-20 / 11-14$ & $15-17 / 11-13$ & $18-20 / 14-16$ & $18-20 / 14-16$ & $17-19 / 12-13$ & $18-19 / 10-11$ \\
\hline
\end{tabular}


Table 2. Some Morphometric Characters of Capoeta pestai populations.

\begin{tabular}{|c|c|c|c|c|c|c|c|}
\hline $\begin{array}{l}\text { Water System } \\
\text { /Characters }\end{array}$ & $\begin{array}{l}\text { Ibrala } \\
\text { Stream } \\
\text { (Yeşildere- } \\
\text { Karaman) }\end{array}$ & $\begin{array}{l}\text { Melendiz } \\
\text { River } \\
\text { (Aksaray) }\end{array}$ & $\begin{array}{l}\text { Kocasu } \\
\text { Stream } \\
\text { (Sarıköy- } \\
\text { Beyşehir) }\end{array}$ & $\begin{array}{c}\text { Sarıöz } \\
\text { Stream } \\
\text { (Beyşehir) } \\
{[17]}\end{array}$ & $\begin{array}{c}\text { Bakaran } \\
\text { Stream } \\
\text { (Derebucak- } \\
\text { Konya) } \\
\text { [17] }\end{array}$ & $\begin{array}{c}\text { Çayköy } \\
\text { Stream } \\
\text { (Eğirdir) } \\
\text { [17] }\end{array}$ & $\begin{array}{l}\text { Lake Eğirdir } \\
\text { [17] }\end{array}$ \\
\hline & $\begin{array}{r}\text { Mean } \pm \text { SE } \\
(\min -m a x .)\end{array}$ & $\begin{array}{c}\text { Mean } \pm \text { SE } \\
(\text { min-max.) }\end{array}$ & $\begin{array}{r}\text { Mean } \pm \text { SE } \\
\text { (min-max.) }\end{array}$ & $\begin{array}{l}\text { Mean } \pm \text { SE } \\
\text { (min-max.) }\end{array}$ & $\begin{array}{l}\text { Mean } \pm \text { SE } \\
(\min -m a x .)\end{array}$ & $\begin{array}{l}\text { Mean } \pm \text { SE } \\
\text { (min-max.) }\end{array}$ & $\begin{array}{l}\text { Mean } \pm \text { SE } \\
(\text { min-max.) }\end{array}$ \\
\hline \multirow{2}{*}{$\begin{array}{l}\text { Standard length } \\
(\mathrm{mm})\end{array}$} & $113.7 \pm 8.82$ & $136.3 \pm 10.1$ & $132.0 \pm 11.6$ & & & & \\
\hline & $(61-143)$ & $(98-173)$ & $(54-207)$ & $(84.4-257.7)$ & $(94.3-256.6)$ & $(74.2-185.8)$ & $(245.5-275.0)$ \\
\hline \multicolumn{8}{|l|}{$\begin{array}{l}\text { In percent of } \\
\text { Standard Length }\end{array}$} \\
\hline \multirow{2}{*}{ Head length } & $28.1 \pm 0.59$ & $27.2 \pm 0.6$ & $29.4 \pm 0.38$ & $26.6 \pm 0.9$ & $26.6 \pm 1.0$ & $27.3 \pm 0.7$ & $25.1 \pm 0.4$ \\
\hline & $(26.2-32.3)$ & $(26.1-28.4)$ & $(27.1-32.4)$ & $(25.6-28.3)$ & $(24.8-28.0)$ & $(25.7-28.5)$ & $(24.5-25.6)$ \\
\hline \multirow{2}{*}{ Body depth } & $24.1 \pm 0.4$ & $23.4 \pm 0.34$ & $24.2 \pm 0.4$ & $22.4 \pm 0.9$ & $22.2 \pm 1.8$ & $21.6 \pm 0.9$ & $23.5 \pm 1.1$ \\
\hline & $(22.2-26.3)$ & $(22.2-24.8)$ & $(22.2-26.8)$ & $(21.1-23.7)$ & $(19.4-24.1)$ & $(21.1-23.7)$ & $(22.2-24.5)$ \\
\hline \multirow{2}{*}{ Predorsal distance } & $49.6 \pm 0.49$ & $50.4 \pm 0.45$ & $51.5 \pm 0.57$ & $53.9 \pm 1.8$ & $52.7 \pm 1.6$ & $53.7 \pm 1.0$ & $53.5 \pm 1.1$ \\
\hline & (47.9-53.0) & $(48.4-53.6)$ & $(48.4-54.0)$ & $(50.8-55.8)$ & $(50.3-54.7)$ & $(52.4-55.5)$ & $(52.5-54.8)$ \\
\hline \multirow{2}{*}{ Preventral distance } & $53.1 \pm 1.57$ & $55.5 \pm 0.45$ & $55.4 \pm 0.71$ & $55.4 \pm 0.9$ & $54.9 \pm 1.1$ & $55.5 \pm 1.2$ & $55.5 \pm 1.2$ \\
\hline & $(50.9-55.2)$ & $(53.7-58.0)$ & $(51.3-59.3)$ & $(53.8-56.8)$ & $(52.9-56.0)$ & $(53.7-56.9)$ & $(53.7-56.9)$ \\
\hline \multirow{2}{*}{ Preanal distance } & $73.4 \pm 0.55$ & $75.4 \pm 0.54$ & $74.5 \pm 0.58$ & $76.6 \pm 1.7$ & $75.5 \pm 1.6$ & $75.4 \pm 0.7$ & $76.9 \pm 1.4$ \\
\hline & $(69.6-75.8)$ & $(73.2-78.1)$ & $(71.0-77.7)$ & $(73.7-79.3)$ & $(73.6-78.0)$ & $(73.7-76.5)$ & $(74.9-78.6)$ \\
\hline \multirow{2}{*}{$\begin{array}{l}\text { Pectoral-ventral } \\
\text { fin origin distance }\end{array}$} & $25.8 \pm 0.5$ & $29.2 \pm 0.61$ & $27.6 \pm 0.67$ & $30.0 \pm 2.0$ & $30.2 \pm 1.3$ & $30.2 \pm 1.0$ & $32.5 \pm 0.9$ \\
\hline & $(23.5-28.7)$ & $(26.9-32.0)$ & $(23.0-31.2)$ & $(26.4-32.7)$ & $(28.7-32.5)$ & $(28.5-31.9)$ & $(31.1-33.3)$ \\
\hline \multirow{2}{*}{$\begin{array}{l}\text { Ventral-anal fin } \\
\text { origin distance }\end{array}$} & $16.1 \pm 0.57$ & $16.2 \pm 0.5$ & $16.0 \pm 0.5$ & $22.4 \pm 1.1$ & $21.9 \pm 1.1$ & $21.2 \pm 1.1$ & $23.1 \pm 0.8$ \\
\hline & $(13.4-19.1)$ & $(14.0-18.9)$ & $(13.0-18.5)$ & $(20.9-23.8)$ & $(20.5-23.8)$ & $(19.5-23.3)$ & $(22.3-24.2)$ \\
\hline \multirow{2}{*}{$\begin{array}{l}\text { Caudal peduncle } \\
\text { length }\end{array}$} & $12.1 \pm 0.32$ & $12 \pm 0.45$ & $11.3 \pm 0.32$ & $17.8 \pm 0.7$ & $17.1 \pm 0.8$ & $16.4 \pm 1.1$ & $18.3 \pm 0.8$ \\
\hline & $(9.67-13.2)$ & $(9.86-13.96)$ & $(9.46-13.3)$ & $(17.1-18.8)$ & $(16.2-18.7)$ & $(14.8-18.5)$ & $(17.1-19.1)$ \\
\hline \multirow{2}{*}{$\begin{array}{l}\text { Caudal peduncle } \\
\text { depth }\end{array}$} & $9.89 \pm 0.47$ & $10.7 \pm 0.11$ & $9.53 \pm 0.16$ & $9.8 \pm 0.5$ & $9.5 \pm 0.8$ & $9.5 \pm 0.6$ & $10.3 \pm 0.4$ \\
\hline & $(9.05-10.4)$ & $(10.1-11.2)$ & $(8.62-10.5)$ & $(8.8-10.5)$ & $(8.1-10.3)$ & $(8.6-10.9)$ & $(9.8-10.9)$ \\
\hline \multirow{2}{*}{ Dorsal fin depth } & $25.0 \pm 0.83$ & $21.6 \pm 0.83$ & $24.2 \pm 0.77$ & $18.6 \pm 2.1$ & $19.0 \pm 2.4$ & $20.1 \pm 1.6$ & $15.8 \pm 1.0$ \\
\hline & $(22.1-30.7)$ & $(17.9-24.9)$ & $(19.2-28.5)$ & $(15.2-21.6)$ & $(15.5-22.9)$ & $(17.8-22.9)$ & $(14.5-16.7)$ \\
\hline \multirow{2}{*}{$\begin{array}{l}\text { Dorsal fin base } \\
\text { length }\end{array}$} & $17.0 \pm 0.29$ & $16.55 \pm 0.38$ & $17.5 \pm 0.34$ & $14.2 \pm 1.0$ & $14.6 \pm 1.5$ & $15.0 \pm 1.1$ & $13.6 \pm 0.9$ \\
\hline & $(15.5-18.2)$ & $(15.1-18.0)$ & $(15.9-19.9)$ & $(12.8-15.8)$ & $(12.4-16.8)$ & $(12.9-17.6)$ & $(12.3-14.8)$ \\
\hline \multirow{2}{*}{ Anal fin depth } & $17.6 \pm 0.37$ & $18.6 \pm 0.39$ & $17.9 \pm 0.33$ & $16.7 \pm 2.5$ & $17.0 \pm 2.0$ & $17.0 \pm 2.6$ & $15.8 \pm 1.9$ \\
\hline & $(16.2-19.4)$ & $(17.2-21.3)$ & $(16.1-19.9)$ & $(12.9-20.6)$ & $(14.6-19.7)$ & $(14.7-22.8)$ & $(12.8-17.8)$ \\
\hline \multirow{2}{*}{$\begin{array}{l}\text { Anal fin base } \\
\text { length }\end{array}$} & $7.9 \pm 0.59$ & $9.2 \pm 0.19$ & $8.11 \pm 0.15$ & $8.0 \pm 0.8$ & $8.0 \pm 0.8$ & $9.0 \pm 1.0$ & $8.1 \pm 0.4$ \\
\hline & $(6.92-8.87)$ & $(8.3-10.3)$ & $(6.76-8.72)$ & $(7.2-9.5)$ & $(7.0-9.7)$ & $(7.2-11.3)$ & $(7.4-8.5)$ \\
\hline \multirow{2}{*}{ Pektoral fin length } & $17.8 \pm 0.66$ & $19.4 \pm 0.22$ & $19.3 \pm 0.43$ & $17.6 \pm 0.8$ & $17.9 \pm 1.3$ & $18.6 \pm 0.9$ & $16.0 \pm 0.5$ \\
\hline & $(13.5-20.7)$ & $(8.5-20.2)$ & $(15.9-21.7)$ & $(16.8-19.1)$ & $(16.3-20.3)$ & $(17.2-20.0)$ & $(15.1-16.4)$ \\
\hline \multirow{2}{*}{ Ventral fin length } & $16.1 \pm 0.29$ & $16.8 \pm 0.28$ & $16.7 \pm 0.27$ & $14.4 \pm 0.7$ & $13.8 \pm 1.1$ & $14.8 \pm 0.8$ & $12.4 \pm 1.1$ \\
\hline & $(14.9-17.2)$ & $(15.7-18.3)$ & $(15.2-18.5)$ & $(13.3-15.7)$ & $(11.9-15.6)$ & $(13.7-16.1)$ & $(10.9-13.4)$ \\
\hline
\end{tabular}


Table 2. Some Morphometric Characters of Capoeta pestai populations. Continued

\begin{tabular}{|c|c|c|c|c|c|c|c|}
\hline \multirow{2}{*}{ Body depth } & $86.3 \pm 2.61$ & $86.2 \pm 1.48$ & $82.4 \pm 1.71$ & $84.5 \pm 3.5$ & $83.7 \pm 5.2$ & $79.1 \pm 2.8$ & $93.6 \pm 3.1$ \\
\hline & $(71.6-94.3)$ & $(80.0-91.0)$ & $(69.7-90.9)$ & $(78.8-89.7)$ & $(74.4-89.1)$ & $(74.2-83.6)$ & $(89.5-96.3)$ \\
\hline \multirow{2}{*}{$\begin{array}{l}\text { Eye diameter } \\
\text { Postorbital } \\
\text { distance }\end{array}$} & $19.5 \pm 1.04$ & $16.7 \pm 0.63$ & $17.8 \pm 0.75$ & $15.0 \pm 1.7$ & $16.2 \pm 2.4$ & $17.0 \pm 2.8$ & $13.2 \pm 1.2$ \\
\hline & $(16.9-24.4)$ & $(14.5-19.4)$ & $(14.6-22.9)$ & $(12.5-17.7)$ & $(12.6-19.3)$ & $(13.5-21.2)$ & $(12.0-14.1)$ \\
\hline \multirow{2}{*}{ Eye diameter } & $50.6 \pm 0.62$ & 54. \pm 0.82 & $53.8 \pm 0.65$ & $53.2 \pm 2.3$ & $50.5 \pm 2.2$ & $48.7 \pm 2.6$ & $52.8 \pm 1.4$ \\
\hline & $(47.9-54.9)$ & $(52.2-60.0)$ & $(50.0-57.9)$ & $(50.4-57.6)$ & $(46.8-53.5)$ & $(44.5-53.4)$ & $(51.4-55.2)$ \\
\hline \multirow{2}{*}{$\begin{array}{l}\text { Postorbital } \\
\text { distance }\end{array}$} & $32.3 \pm 0.36$ & $34.0 \pm 0.52$ & $30.2 \pm 0.72$ & $37.6 \pm 2.1$ & $38.5 \pm 3.3$ & $38.6 \pm 1.9$ & $38.5 \pm 1.2$ \\
\hline & $(30.5-34.1)$ & $(31.2-35.9)$ & $(26.6-34.6)$ & $(33.5-40.1)$ & $(35.2-44.3)$ & $(35.8-41.6)$ & $(37.0-39.8)$ \\
\hline \multirow{2}{*}{$\begin{array}{l}\text { Interorbital } \\
\text { distance }\end{array}$} & $58 \pm 1.08$ & $57.0 \pm 0.64$ & $56.4 \pm 0.99$ & $62.9 \pm 1.6$ & $62.0 \pm 1.9$ & $61.7 \pm 1.9$ & $66.5 \pm 1.5$ \\
\hline & $(51.8-62.8)$ & (54.1-59.9) & $(50.3-63.2)$ & $(60.7-65.5)$ & $(58.2-64.1)$ & $(59.0-65.6)$ & $(64.7-68.5)$ \\
\hline \multirow{2}{*}{$\begin{array}{l}\text { Head depth at } \\
\text { interorbital region }\end{array}$} & $50.9 \pm 1.15$ & $50.6 \pm 1.11$ & $48.6 \pm 1.66$ & $54.1 \pm 2.3$ & $53.2 \pm 2.5$ & $54.5 \pm 2.0$ & $59.1 \pm 0.9$ \\
\hline & $(45.7-56.3)$ & $(46.0-55.1)$ & $(36.6-57.5)$ & $(51.0-58.2)$ & $(49.2-56.9)$ & $(49.9-56.8)$ & $(58.1-60.2)$ \\
\hline \multirow{2}{*}{$\begin{array}{l}\text { Head width at } \\
\text { posterior margin } \\
\text { op eyes } \\
\text { Mouth width }\end{array}$} & $22.6 \pm 0.32$ & $23.6 \pm 0.45$ & $20.3 \pm 0.4$ & $24.6 \pm 1.6$ & $24.6 \pm 1.5$ & $29.3 \pm 0.9$ & $29.3 \pm 0.9$ \\
\hline & $(21.1-23.9)$ & $(21.4-25.0)$ & $(18.6-23.2)$ & $(21.9-26.7)$ & $(22.4-26.5)$ & $(28.3-30.7)$ & $(28.3-30.7)$ \\
\hline \multirow{2}{*}{ Length of barbel } & $12.8 \pm 0.36$ & $13.5 \pm 0.59$ & $13.8 \pm 0.76$ & $13.8 \pm 1.4$ & $12.9 \pm 1.7$ & $14.6 \pm 0.7$ & $14.6 \pm 0.7$ \\
\hline & $(11.1-14.3)$ & $(10.8-15.9)$ & $(5.71-16.8)$ & $(11.3-15.6)$ & $(10.7-15.6)$ & $(13.8-15.5)$ & $(13.8-15.5)$ \\
\hline
\end{tabular}

Küçük et al. [17] reported that the populations between the Lake Eğirdir and Lake Beyşehir basin systems showed significantly important morphological differences, but this differentiation was not significant at the species or subspecies level. When we examine the details in Table 2, we can see clearly the overlap occurred among these populations. These differences may be arisen from the lentic and lotic habitat and the size group and sex of the specimens.

Capoeta pestai which is distributed in the Eğirdir Lake Basin and C. mauricii which is endemic to Lake Beyşehir show same genetic difference but they are different in terms of morphological characters [24]. Levin et al.[25], taken into consideration only Beyşehir Lake specimens so in this study they did not compare C. mauricii with $C$. pestai. Studies carried out the molecular phylogeny of the genus Capoeta in Anatolia by Bektaş et al (2017), C. mauricii is within the Subclade III of Clade I (small scale). Bektaş et al. [26] are also mentioned that C. mauricii which is endemic to Lake Beyşehir, compared with its sister taxa Capoeta pestai (Gediz River Basin) and C. aydinensis (Büyük Menderes River Basin), and separated from sister taxa approximately 6.23 Mya. However, they did not compare C. mauricii with $C$. pestai which is dist-

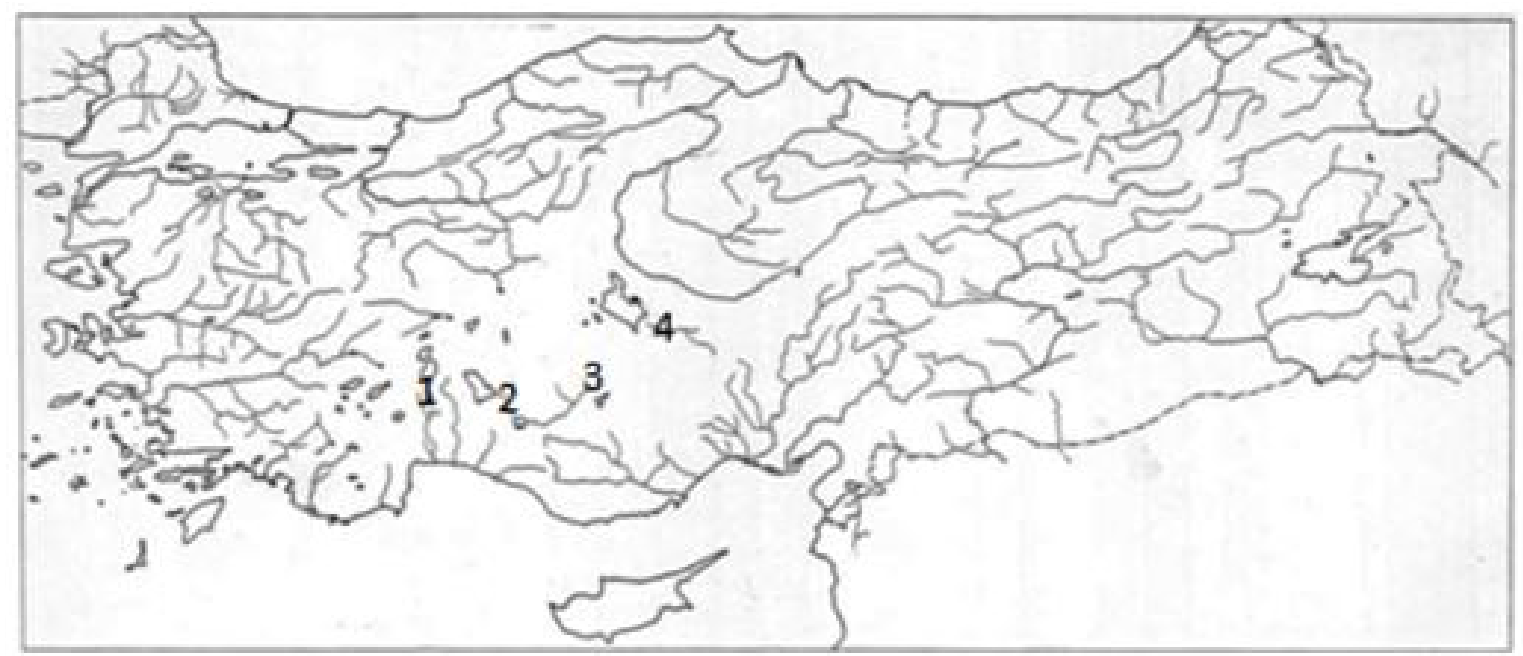

Figure 1. The goegraphic distribution of Capoeta pestai in Turkey. 1: Lake Eğirdir; 2: Lake Beyşehir; 3: Melendiz Sream; 4: İbrala Stream. 
ributed in the Eğirdir Lake Basin. According to the Ph.D. thesis of Özdemir [27], there are no significant genetic differences between Beyşehir population, Melendiz population and the ibrala population of $C$. pestai (genetic differences for COI gene; \%0-\%0,2). However, there are no genetic differences between Beyşehir Lake population which were described as C. mauricii by Küçük et al. [8], and Eğirdir Lake population (according to GenBank: KJ552841 and KJ552918). In evaluating these findings, C. mauricii is the synonym to $C$. pestai.

Moreover, the population density of $C$. pestai inhabited in the Ibrala Stream, the Melendiz River, and The Kocasu Stream were determined fairly low and the generation of this species was at risk. When we take into consideration that this species is an endemic and critically endangered species, recognition of morphological and genetic variations among and within populations is important for its conservation.

Acknowledgments - We pleased to thank Ibrahim Aslan for his help during field sampling.



Figure 2. Capoeta pestai, ibrala Stream-Yeşildere, Konya Closed Basin.

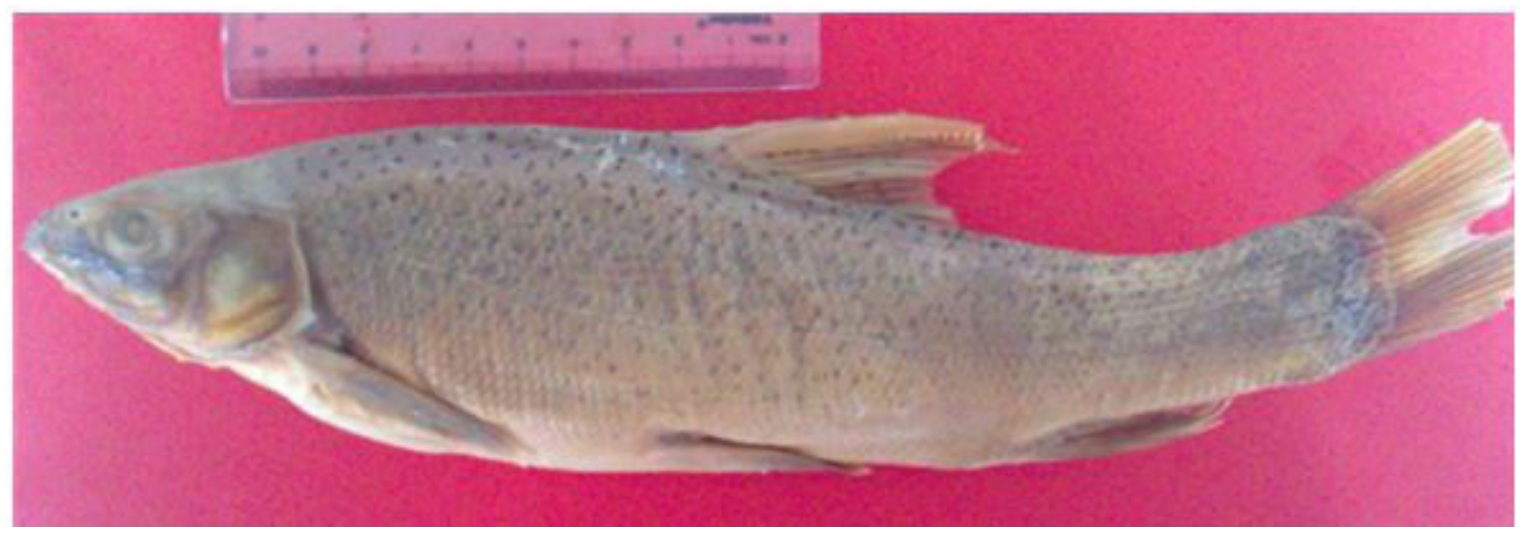

Figure 3. Capoeta mauricii (standart lenght: 265 mm, Beyşehir Basin. 


\section{References}

1. M.S. Karaman, Sübwasserfische der Turkei 7. Teil. Revision der kleinasiatischen und vorderasiatischen Arten des genus Capoeta (Varicorhinus, partim), Mitt. Hamburg Zool. Mus. Inst. Band, 66 (1969) 17-54.

2. P. M. Banarescu, Freshwater Fishes, Wiesbaden: Aula-Verl, Volume 1 (1990) 6-23.

3. D. Turan, M.Kottelat, S.G. Kirankaya, S. Engin, Capoeta ekmekciae, a new species of cyprinid fish from northeastern Anatolia (Teleostei: Cyprinidae), Ichthyological Exploration of Freshwaters, 17 (2006) 147-156.

4. D. Turan, M. Kottelat, F.G. Ekmekçi, H.O. Imamoğlu, A review of Capoeta tinca, with descriptions of two new species from Turkey (Teleostei: Cyprinidae), Revue Suisse de Zoologie, 113 (2006b) 421- 436.

5. M. Özuluğ, J. Freyhof, Capoeta turani, a new species of barbel from River Seyhan, Turkey (Teleostei: Cyprinidae), Ichthyological Exploration of Freshwaters, 19 (2008) 289 296

6. D. Turan, M. Kottelat, F.G. Ekmekçi, Capoeta erhani, a new species of cyprinid fish from Ceyhan River, Turkey (Teleostei: Cyprinidae), Ichthyol. Explor. Freshwat., 19 (2008) 263-270.

7. C.Schöter, M.Özuluğ, J. Freyhof, Capoeta caelestis, a new species from Göksu River, Turkey (Teleostei: Cyprinidae) Ichthyol, Explor. Freshwaters, 20 (2009) 229-236.

8. F. Küçük, D.Turan, C.Şahin, I.Gülle, Capoeta mauricii n. sp., a new species of cyprinid fish from Lake Beyşehir, Turkey, Zoology in the Middle East, 47(2009)71-82

9. M.Elp, M. I. Osmanoğlu, A.E. Kadak, D. Turan, Characteristics of Capoeta oguzelii, a new species of cyprinid fish from the Ezine Stream, Black Sea basin, Turkey (Teleostei: Cyprinidae), Zoology in the Middle East 64 (2018) 1-11.

10. D. Turan, F. Küçük, C. Kaya, S.S. Güçlü, Y. Bektaş, Capoeta aydinensis, a new species of scraper from southwestern Anatolia, Turkey (Teleostei: Cyprinidae), Turk. J. Zool., 41 (2017) 436-442.

11. F. Erkakan, F.Özdemir, Revision of the fish fauna of the Seyhan and Ceyhan river basins in Turkey, Res. J. biol. Sci., 6(2011) 1-8

12. F. Özdemir, Principle Components Analysis of Two Pairs of Barbels Species of the Genus Capoeta (Teleostei: Cyprinidae) in Turkey, Pakistan J. Zool., 47 (2015) 753-762.

13. V. Pietschmann, Drei neue Fisharten aus Kleinasien, Mat. Nat. KI. Wien, 70 (1933) 21-23.

14. Freyhof, J. 2014. Capoeta pestai. The IUCN Red List of Threatened Species, 2014

15. W. Ladiges, Süsswasserfische der Türkei 1. Teil Cyprinidae, Mitteilungen des Hamburgischen Zoologischen Museums und Instituts, 58 (1960) 105-150.
16. A.Ü. Erdemli, Beysehir Gölü Balıkları. Selçuk Üniversitesi Fen Fakültesi Dergisi, 2 (1982) 131-142

17. F. Küçük, İ İ. Turna, O. Demir, Capoeta pestai (Pietschmann, 1933) (Pisces: Cyprinidae)'nin yayılış alanı ve taksonomik özellikleri, S.D.Ü. Fen Bilimleri Dergisi,11 (2007) 18-25.

18. M. Kottelat, R. Barbieri, Pseudophoxinus laconicus, a new species of minnow from Peloponnese, Greece, with comments on the West Balkan Pseudophoxinus species (Teleostei: Cyprinidae), Ichth. Exp. Freshwaters, 15 (2004) 147-160.

19. K. Watanabe, Parsimony analysis of the distribution pattern of Japanese primary freshwater fishes, and its application to the distribution of the bagrid catfishes, Ichthyological Research 45 (1998) 259-270.

20. J.C. Marr, The problem of defining and recognizing subpopulations of fishes. In: Contributions to the study of subpopulations of fishes, Ed. by J. C. Marr. Washington: Gov't. Printing Office (1957) 1-6.

21. M.Y. Ali, C.C.Lindsey, Heritable and temperature induced meristic variation in the Medaka, Oxyzias latipes, Can. J. Zool., 52 (1974) 959-976.

22. R. K. Johnson, M. A. Barnett, An inverse correlation between meristic characters and food supply in mid-wate fishes: evidence and possible explanations, In: Readings in ichthyology, Ed. by M. S. Love and M. M. Cailliet, Santa Monica CA: Goodyear Publishing Co. Inc., (1979) 49-62.

23. E.D. Vasil'eva, Variation of the external characters and taxonomic relationships of Azov and Black-Sea populations of Percarina demidoffii (Percidae), J. Ichthyol., 46 (2006) 292-300

24. M.F. Geiger, F. Herder, M.T. Monagham, V.Almada, R.Barbieri, M. Bariche et al. Spatial heterogeneity in the Mediterranean biodiversity hotspot affects barcoding accuracy of its freshwater fishes, Mol. Ecol. Resour., 14 (2014) 1210-1221.

25. B.A. Levin, J.Freyhof, Z.Lajbner, S.Perea, A. Abdoli, M.Gaffaroğlu, Phylogenetic relationships of the algae scraping cyprinid genus Capoeta (Teleostei: Cyprinidae), Mol Phylogenet Evol., 62 (2102) 542-9.

26. Y. Bektaş, D.Turan, İ. Aksu, Y. Çiftçi,O. Eroğlu, G. Kalaycı, A.O. Belduz, Molecular phylogeny of the genus Capoeta (Teleostei: Cyprinidae) in Anatolia, Turkey, Biochem. Systemat, Ecology, 70 (2017) 80-94.

27. F. Özdemir, Türkiye'deki Capoeta (Teleostei: Cyprinidae) cinsine ait tür ve alttürlerin klasik sistematik ve moleküler sistematik yöntemler kullanılarak revizyonu, D6509, Hacettepe Üniversitesi, Doktora tezi, 2013. 